\title{
DEVELOPMENT OF RESOURCE SAVING STRATEGY IN ECONOMIC ACTIVITY OF AGRICULTURAL EN- TERPRISES
}

\begin{abstract}
This article is dedicated to the development of an effective strategy for resource saving, to encourage the process of investing in resource saving technologies and the introduction of an efficient program for resource saving, especially in an agricultural enterprise, which has their own specific features.

The basic idea behind most of the individual measures proposed in our strategy is to encourage efficient behavior in a way that it is compatible with an incentive while leaving the details of individual measures open and not making them mandatory. In this way the existing market mechanisms would hardly be affected. Resource saving strategy is built upon ecologically clean agriculture production and related practices to accelerate the application of preventive environmental strategies to processes, products and services to increase efficiency and reduce risks to humans and the environment. The efficient use of the production potential of agricultural production in a general form is an essence of resource saving strategy. Reducing the resource usage could be achieved only to the limits technology factors, which could be lowered by the introduction of resource-saving crop rotation, introduction of low-cost technologies and new varieties. Saving technologies aim at reducing direct labor, materials and production processes, environmental compliance impacts on land resources, improving the quality and stability of production and profit. Taking into account all the issues listed above, we in the article proposed concept of resource saving strategy in economic activity of agricultural enterprises.
\end{abstract}

Keywords: resource saving, strategy, economic activity, agricultural enterprises, features of agricultural strategy

Resource limitations forces agricultural enterprises to seek reserves in their rational use. Rate of growth of agricultural production depends on the feasibility of these resources. Due to financial crisis, agricultural producers could not count on substantial financial support. Therefore, in these circumstances, the role of the rational, economical and efficient use of resources is drastically increasing. Moreover, under the resource saving is understood not the restriction of their use, but introduction of resource-saving technologies, capable for the same amount of resources to increase agricultural production.

Resource saving is a complex problem, solution of which requires a focused investment, financial, credit, tax, legal, scientific and technical policy [7]. An important contribution to the research of resource saving problem belongs to the Ukrainian scholar such as O. Batur, P. Haidutsky, V. Geets, S. Denisyuk, S. Dorohuntsov, M. I. Dolishniy, B. M.

\footnotetext{
${ }^{1}$ Nataliia Gerasymchuk, PhD in Economics, associate professor of Economics of Enterprise Department of National University of Life and Environmental Sciences of Ukraine, 80 Verchovynna Str, Apt 26 Kyiv, Ukraine 03179, e-mail: 90999nag@mail.ru.
} 
Danylyshyn, I. Lukin, Y. Nikolenko, M. Malik, B.Panasyuk, G. Pidlisetsky, V. Rossokha, M. Sadykov, P. Sabluk, V. Tregobchuk, V. Yurchyshyn.

However, the main problem of the study is to develop an effective resource saving strategy in economic activity of agricultural enterprises, encourage the process of investing in resource saving technologies and the introduction of resource efficient programs.

Thus, objectively necessary and urgent problem is to strengthen resource in the Ukrainian economy, particularly in agriculture, which is characterized by very high recourse input, so the problem should be characterized on all levels of management. Thus, the problem of resource development in the agricultural economy of Ukraine is extremely important, which make this topic up-to-date.

Certainly, gained from research material provides a good basis for further research in this area, though number of methodological and practical problems of strategy of resource saving in agricultural sphere still exists and requiring solution.

Changing market conditions caused by the financial crisis of 2008 led to a temporary progressive growth of prices for agricultural products compared with the increase of prices for the capital and current assets, which resulted in increasing of demand for products of domestic manufacturers. Receiving additional revenue, enterprises are distributing it, as a rule, only for current needs and maintaining of traditional structures and manufacturing technologies. But strict orientation on maximum profit in a short time on temporarily established situation leads to the lack of future development. Critical analysis of a substantial number of published articles or materials on long-term development of Ukraine, restructuring, reproductive relationships, social issues, the economy out of the crisis, etc. showed that the recognition of the strategic nature of agriculture, at best, is wishful thinking, it is still underestimated by the critical role of the agricultural sector in achieving sustainable economic growth.

Basic mass of scientific research on agricultural issues devoted to the study of institutional change primarily in rural areas, while the global experience, and the logic of the reproduction cycle, show a direct relationship of economic reform on the level of efficiency and technological progress $[4,9]$. The isolation of the socio-economic and institutional reforms in rural areas from the material and technical base of agricultural production was one of the main reasons that the reform is not only not provide any tangible results, but, on the contrary, further complicate the situation in the agricultural sector [4].

Meanwhile, at a time when it comes to transition the economy to a resource-saving type of reproduction, its aim to ensure sustainable economic growth and the creation of favorable conditions for people needs to reassess the role and place of agricultural sector. This is explained by the following reasons:

First, the agricultural sector is by its very nature has always been, is, and will hold a special place in the Ukrainian economy. The extent of its development is largely determined by the level of well-being, physical and spiritual health of the nation, the moral basics of society, socio-economic and political situation in the country and, finally, its political and economic security.

Secondly, agriculture is one of the few industries whose products are even in compressed domestic market has a relatively stable mass effective demand, and its huge potential enabling agriculture enterprises to meet such demand. This creates a very real prerequisite for revival of agricultural production.

Third, agriculture itself forms quite significant potential demand for many industry products: trucks, tractors, machinery, farm machinery and equipment, construction mate- 
rials, fertilizer, etc. In the case of recovery of agricultural production producers of goods and services consumed in agriculture, in turn, pull the chain of development of other industries, such as enterprises processing agricultural products.

Fourth, the agricultural sector has the unique in its way labor potential, which is characterized by the low mobility of labor. Analysis of the movement of labor in the economy during the period 2006-2010 showed that the lowest average wage rate of labor turnover (sum of the coefficients of hiring and firing) in agriculture was 1.7 times lower than for the whole economy, 1.8 times lower than in industry, three times - in construction, 1.9 times - in transport, 2.1 times - to trade[8]. For the labor market low labor mobility is not very favorable, but for the production - on the contrary, this is one of the prerequisites for increasing long-term interest of the enterprise, as well as increase motivation to work.

Fifth, the agrarian economy by its very nature is a socially oriented market economy and therefore is the best establishment of the state course of socio-economic policy.

Finally, one cannot ignore the fact that Ukraine, in common sense, would never be able to abandon development of its agricultural economy, which is a vital part of social reproduction. Its special role in the socio-economic development of the society that it can and should do, is determined by the production of food (including food for children, the production of which in recent years have particular importance) as the basis of human activity and reproduction of the labor force, the production of raw materials for the manufacture of many of non-food consumer goods and capital goods, the reproduction of land as indispensable element of material production. The degree of development and the level of efficiency of agriculture are largely depending on the balance of the economy as a whole, the state budget and budget of households.

At the same time, agriculture is one of the most resource intensive industries. For example, for the production of one nutritious calorie that a person receives from agricultural products is spent about 10 calories of energy. However, the problem of high resource intensity of agriculture is not purely Ukrainian. In the U.S., for example, a doubling of crop yields was accompanied by a ten-fold increase in the energy cost of mechanization and use of chemicals. It is estimated that the average American farmer uses during the year one million hectoliters of oil, about 40 billion kilowatt-hours of electricity, 19 million tons of mineral fertilizers (in terms of nutrient)[5]. Yet industrialized countries have opted for progressive saturation of agricultural production systems of machines and technologies, while improving the organization of production, more efficient use of all types of productive resources, including land and labor. The experience of these countries shows that the increase in the yield of the final product while using less raw material, provided the transition of processing industries to more advanced, high-efficiency technology. For example, for the production of 1 ton of sugar in our country is spent 7.6 tons of sugar beets, and in Germany, France, Austria - 6.5-7 tons, for 1 ton of starch - 8-9 tons of potatoes, as in some other countries - 5-5,5 t-efficient technology for processing raw material can significantly reduce its losses and increase the production of the final product[5].

Therefore it is not quite reasonable claims, often expressed in relation to domestic agriculture, that it uses too many industrial raw materials, energy without adequate return. Even in the era of socialism, in which was applied much scientific efforts to create alternative technologies that provide agricultural labor productivity growth has not been 
solved even with the high cost of all resources, which was not entirely the fault of the agricultural sector.

It is impossible not take into consideration that in the last decades environmental problems had sharply deteriorated and associated with the development of agricultural production. Therefore, we have the need to solve the problem of resource saving in the agricultural sector in the nearest time in order to prevent larger consequences. Largely for these reasons, agriculture has been chosen as the subject for a more detailed study of the problem of resource saving strategy.

Because at this stage the problem of increasing the efficiency of management of agricultural enterprises is directly related to the need of intensifying and strengthening enterprises capabilities while overcoming chaotic internal state and external activity, achieving greater predictability of their operation, the role of strategic planning at the level of production s cannot be overstated.

The introduction of strategic planning will solve the problem matching between production and reproduction processes, coordinate the activities of the various subsystems of the enterprise and enhance its capacity [Shumpeter, 1950].

G. Kleiner [6] described strategic solutions as solutions that are crucial to the functioning of business and involve (if desired) long and anticipated consequences, concludes that the implementation of strategic decisions is changing potential of the company. G. Kleiner rightly points out that decisions of this kind are taken sooner or later in any enterprise, even those that do not use the concept of strategy. The disadvantage of this situation is that, without distinguishing strategic decisions within tactical and operational, entrepreneurs virtually ignored the need for justification of the development strategy.

Grand significance to the strategy development has paid Schumpeter [6]. He considered the concept of "entrepreneurial firm" as a separate economic entity, competing through the introduction of new products, new technologies and new sources of raw materials, or new types of organization as the strategy of survival. Innovation in the last decades focused mainly on increasing labour productivity, without at the same time promoting resource and capital productivity and reducing the environmental impacts of growth. A new economic paradigm must find a firm footing in future political, economic and social discourse and must be mainstreamed in all aspects of life.

The essence of the transition to a resource-saving model for all industries and sectors of the economy is the same. But the ways, forms, conditions of its implementation are important specific features, which, if ignored, could have serious negative consequences. These features exist due to the specifics of each particular industry and trends of development and should therefore be reflected in the mechanism of resource saving strategy. This primarily refers to agricultural production, which is of particular socio-economic system. Structural element in agricultural production, in addition to the existing, are the climatic and biological factors, which are based on the land and wildlife, and on the one hand are working on natural laws, and the other - are limited and hard to recover resources. This fact greatly complicates the formation mechanism of resource saving in the agricultural sector, as it should focus not only on the maximum savings of materialized and living labor, but also on the rational use of land and biological potential which is subject to constant coordination of production without violations of environmental requirements and habitat destruction. The limited scope of the natural features of resources (including land and biological) capacity to meet the ever growing needs of the society in 
agricultural production by increasing the volume of production should be considered first and foremost when choosing the direction of intensification of agricultural production.

Another important feature of agriculture, which cannot be ignored in the formation of resource saving strategy, due to the specificity of its transition to a resource-saving type of reproduction, is the fact that under the influence of the scientific and technological revolution and the deepening of the social division of labor agriculture integrated with supplying branches and spheres. The development of this progressive growth process of integration of agricultural production has led to the emergence of a qualitatively new subsystem of the economy - agriculture, covering all stages of food production from means of production for agricultural enterprises, production of raw agricultural products, processing and finishing products and bringing it to the consumer. Reforms of the productive agricultural sector alone have led to the destruction of agriculture complex as a whole system. Without restoration of its integrity, sustainable economic growth is not possible, so part of the strategy of resource saving must be oriented to its recovery.

Summarizing management and economic science, based on specific features of agricultural enterprises, we are proposing next effective resource-saving strategy for agricultural enterprises in Ukraine (fig.1)

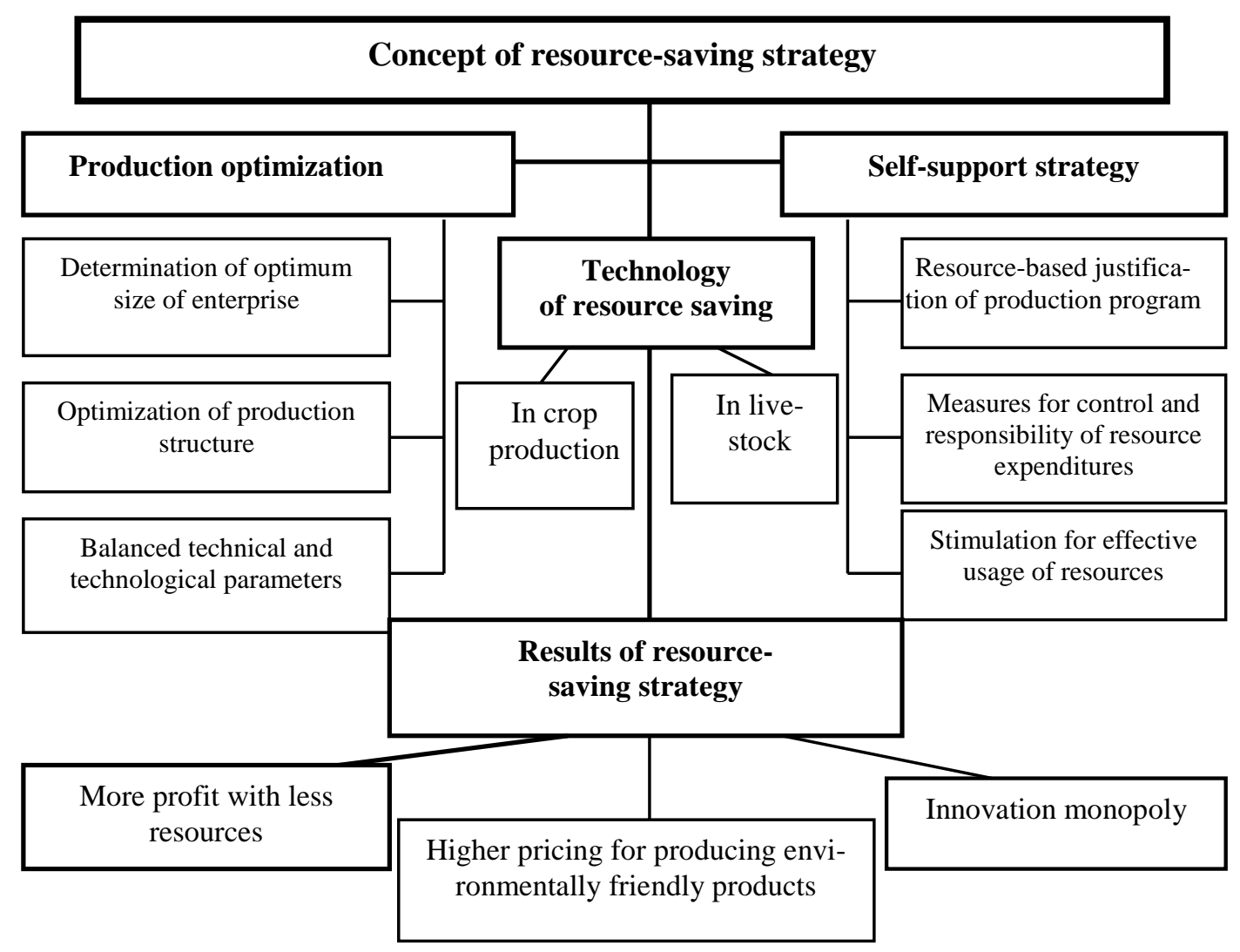

Figure 1. Concept of resource saving strategy in economic activity of agricultural enterprises 
The basic idea behind most of the individual measures proposed in our strategy is to encourage efficient behavior in a way that is compatible with incentive while leaving the details of individual measures open and not making them mandatory. In this way existing market mechanisms would hardly be affected.

By the laws of open market entrepreneurial freedom should not be restricted, so the issue of resource efficiency must be disseminated by raising awareness and be integrated into entrepreneurs' competency and qualification profiles [2]. In addition, ecological and/or resource-saving technologies should be promoted in enterprise-oriented innovation and research processes as part of the global movement toward sustainable agriculture [1].

Since the necessary advances in resource efficiency can only be realized by means of radical system innovations, further measures using existing policy instruments will be required [10]. These would aim to accelerate the spread of resource-efficient products, technologies and processes and innovation activity. In other words, application of the policy mix would begin at several points simultaneously.

Individual instruments may be chosen from the portfolio of enterprise-related instruments in strategy (comprising eight individual measures) to enable an easier start to the program of action. With the measures resulting from the other directions of production activity, especially finance and investment, proposed measures must be merged with the enterprise policy. In the long term, however, it would be preferable and practical to implement the individual measures as a package because they build on one other and have been coordinated and hence promise more lasting success in resource efficiency in different types of enterprise activity.

Resource saving strategy builds upon ecologically clean agriculture production and related practices to accelerate the application of preventive environmental strategies to processes, products and services to increase efficiency and reduce risks to humans and the environment.

[1]:

Strategy addresses the three sustainability dimensions individually and synergistically

- Production Efficiency: optimization of the productive use of natural resources (materials, energy and water);

- Environmental management: minimization of impacts on environment and nature through reduction of wastes and emissions; and

- Human Development: minimization of risks to people and communities and support for their development.

Resource saving strategy has been, and continues to be, achieved by applying knowhow from regular training, improving technologies, better process control and technology change. Operational improvements and good-housekeeping options could be implemented at running costs for like activity. The environmental part of resource saving strategy includes the following measures: monitoring water consumption and wastewater generation through metering and sub-metering of all usage and discharge points; development of key performance indicators and monitoring productivity levels; improving agriculture operations; manure management with study of possibility of catching methane and recycle it for heating, monitoring of efficiency and establishing a preventive maintenance program to control leakages, spills and overflows.

Various „low investment cost“ options of better process control and equipment modification should be implemented including process monitoring. Further measures include 
installation of inclined screens to avoid overflow losses and installation of water saving devices such as borehole pump timers, effluent control pumps and level transmitters. This was a high investment cost option, which led to multiple benefits in terms of decreased resource use.

Efficient use of the production potential of agricultural production in a general form shown is an essence of resource saving strategy. Resource saving strategy is understood as the most efficient use of labor, land, water and material resources to ensure the consistent reduction of resource production, i.e. reduction in the unit cost of each type of inputs per unit of production. As the main goal of strategy realization is efficient use of available resources, enterprises using this strategy develop economic, organizational, technical and informational resource-saving activities. Resource capacity is one of the starting point indicators, showing how many units of resources contained in a unit of the product. For a more accurate description of the combined resources of the actual resource consumption should be compared with normative depending on the quality of land, the level of intensity of use of resources and their concentration. Comparison with the actual resource-regulatory permits to reveal additional reserves increase the efficiency of agricultural production. The degree of efficiency is higher in those agricultural enterprises where norms of resource capacity are higher than actual.

Reducing the resource usage could be achieved only to the limits technology factors, which could be lowered by the introduction of resource-saving crop rotation, introduction of low-cost technologies and new varieties. Saving technologies aimed at reducing direct labor, materials and production processes, environmental compliance impacts on land resources, improving the quality and stability of production and profit. Prerequisites for such technology are the high standard of farming, crop rotation, the availability of machinery and skilled labor.

\section{REFERENCES}

[1] FAO. 2002. Agriculture: towards 2015/2030. Rome. 420 pp.

[2] Ickes B. From the enterprise to company: Notes on the theory of enterprise transition [Text] / W. Ickes, R. Ryterman / / Problems of Economics. - 1994. - № 8. (in Russian)

[3] Kleiner G.B. Strategy of enterprise - Moscow, Publishing House "Case", 2008. - 568 c. (in Russian)

[4] Malik M.I. Sustainable development of rural areas on the basis of regional environmental and ecological agricultural production. / M.I. Malik, M.A. Hvesyk // Economics of agricultural complex. - 2010. - № 5. (in Ukrainian)

[5] Reform and development of agricultural production enterprises [Text]: questions and answers / Editors. P.T. Sabluk; Colective of authors: V.M Aleksiichuk, L.A. Artykulnyy, V. Yurchyshyn et al. - K.: IAE UAAS, 1999. - 362 p. (in Ukrainian)

[6] Schumpeter, Joseph A (1950). Capitalism, Socialism, and Democracy: Third Edition Harper Perennial Modern Classics, 2008 - 464 p.

[7] Sotnyk I.M. Trends and problems of management of production and consumption dematerialisation // Actual problems of economy - 2012. - № 8. - C. 62-67.

[8] Statistical Yearbook "Agriculture of Ukraine" for 2011. - Kyiv: State Statistics Service of Ukraine, 2012. - $386 \mathrm{p}$

[9] The concept of the State program for sustainable development of rural areas by 2020 [Cabinet of Ministers of Ukraine № 121-p from February 3th, 2010] / / Government Courier. - 2010. - March 3 (in Ukrainian) 
[10] Towards a Sustainable Economic Paradigm: From Labour to Resource Productivity - Proceeding for the conference // UNEP DTIE, 2013 http://www.unep.org/dtie/Portals/126/At_a_glance_UK.pdf

\section{ROZWÓJ STRATEGII OSZCZEDZANIA ZASOBÓW W DZIALALNOŚCI PRZEDSIĘBIORSTW ROLNYCH}

Artykuł ten jest poświęcony opracowaniu efektywnej strategii na oszczędzanie zasobów, wspieranie procesu inwestowania w technologie oszczędzania zasobów i wprowadzenie skutecznego programu oszczędzania zasobów w przedsiębiorstwach, zwłaszcza w przedsiębiorstwach rolniczych, które posiadają specyficzne cechy.

Podstawową ideą większości działań zaproponowanych w strategii jest wspieranie efektywnego zachowania w sposób, który jest zachętą, a nie obowiązkiem. Strategia opiera się na oszczędności zasobów ekologicznie czystej produkcji rolniczej i związanych z nią praktykami stosowania profilaktyki środowiskowej, strategii procesów, produktów i usług, w celu zwiększenia wydajności i zmniejszenia ryzyka dla ludzi i środowiska. Efektywne wykorzystanie potencjału produkcyjnego produkcji rolnej w ogólnej przedstawionej formie jest esencją strategii oszczędzania zasobów. Zmniejszenie zużycia zasobów może zostać osiagnięte jedynie w granicach czynników technologicznych, które mogą być obniżone przez wprowadzenie oszczędzania zasobów płodozmianu, wprowadzenie tanich technologii i odmian nowych. Technologie oszczędnościowe mają na celu ograniczenie bezpośredniej robocizny, materiałów i procesów produkcji. Biorąc pod uwagę wszystkie problemy wymienione powyżej, w artykule zaproponowano koncepcję oszczędzania zasobów w działalności gospodarczej przedsiębiorstw rolniczych.

Słowa kluczowe: oszczędność zasobów, strategia, działalność gospodarcza, przedsiębiorstwa rolnicze, strategie rolne.

DOI: 10.7862/rz.2013.mmr.4

Teks złożono w redakcji: styczeń 2013

Przyjęto do druku: czerwiec 2013 